\title{
The application of an anaerobic baffled reactor to produce biogas from kitchen waste
}

\author{
A. Malakahmad ${ }^{1}$, N. Ahmad Basri ${ }^{2}$ \& S. Md. Zain ${ }^{2}$ \\ ${ }^{1}$ Universiti Teknologi PETRONAS, Malaysia \\ ${ }^{2}$ Universiti Kebangsaan Malaysia, Malaysia
}

\begin{abstract}
The tremendous increase in solid waste generation is an unavoidable occurrence due to the fast growing urbanisation and industrialisation in Malaysia. Anaerobic digestion of organic wastes is receiving more attention in recent years throughout the world because the biomethanogenesis process decomposes organic matter to produce methane gas, which is an excellent energy source as fuel in combined heat and power units. In this study, an application of an anaerobic baffled reactor (ABR) for the production of biogas from kitchen waste was carried out to identify the optimum efficiency of methane gas generation and the potential usage of sludge as organic fertiliser. Different proportions of kitchen waste and activated sewage sludge were mixed and tested in the reactor to achieve the best amount of methane production in the shortest time. Results showed that the combination of $75 \%$ of kitchen waste and $25 \%$ of activated sewage sludge yielded the best result, which was $74.1 \%$ of methane gas. Further, determination for fertiliser value from tests on the sludge in the reactor showed its potential for future use in composting. The amounts of N, P and K were $0.95,0.80$ and $0.45 \%$ respectively. According to the observation, anaerobic digestion of kitchen waste in the ABR is able to provide a vital element in an integrated solid waste management and the energy production from this system could be a good reason for many communities to start recycling valuable resources and hence achieving zero waste production.
\end{abstract}

Keywords: anaerobic baffled reactor, kitchen waste, biogas production.

\section{Introduction}

In many countries such as Malaysia, it is increasingly more difficult to find suitable locations for landfills, which are accepted by the population. These circumstances are to be found all over the world and make new strategies for waste 
management necessary. In addition, the promotion of waste minimization and recycling are important components of modern waste management strategies [1].

There are perceptible advantages of anaerobic systems over aerobic metabolic systems and these have been widely reported in the last four decades [2]. There are three clear advantages of the anaerobic treatment over aerobic degradation of organic substrates: the high product and low biomass yield resulting in a limited generation of waste sludge as an unwanted side product; the in situ separation of the product as biogas, limiting costs for product separation; and the use of simple technology, as mixing by the biogas produced circumvents the need for other mixing requirements [3].

Currently, digesters are concentrated in developing countries, with over 5 million household digesters constructed in China and India alone [4]. Digesters built around the world vary in their design complexity, construction materials, and costs. In developed countries, digesters often are concrete stirred tank reactors (CSTRs), in which a portion of the produced biogas is utilized to heat the digester [5]. In developing countries, many of the digesters do not have mixing components, do not require continuous monitoring, and are adaptable to any tropical climate [6]. An anaerobic baffled reactor (ABR) initially receives the organic fraction of municipal solid waste (OFMSW) followed by a decomposition process of the materials and eventually produces biogas by microorganisms' activities. Biogas is an excellent source used as fuel in combined heat and power units. The sludge that produced from this system includes body of microorganisms, which can be applied as a source of organic fertilizer [7].

In this study, an anaerobic baffled reactor was proposed for the recovery of energy and production of organic fertilizer. A modified design of ABR was carried out using different combinations of kitchen waste and activated sewage sludge to achieve the highest biogas and methane generation in the shortest time. The sludge produced in the anaerobic system is examined based on its usage as a source of organic fertilizer and to make the ABR a system by completely using all of the materials throughout the system.

\section{Methods}

\subsection{Reactor configuration}

Additional vertical baffles in a plug-flow reactor constitute an ABR, which enhances solids retention to allow better substrate accessibility to methanogens [8]. The laboratory-scale unit shown in fig. 1 was made with a total volume of 85 liters. Two tanks as influent tank and effluent tank were designed for feeding and removing the materials to and from the reactor. A gas collector was also provided for collection, calculation and analysis on the amount of biogas. The dimension of the laboratory-scale unit was $75 \mathrm{~cm}$ length, $42 \mathrm{~cm}$ height and $27 \mathrm{~cm}$ depth. The down-flow chambers were $3 \mathrm{~cm}$ above the reactor's bottom to route the flow to the center of the up-flow chamber to achieve better contact and greater mixing the feedstock and solids. 


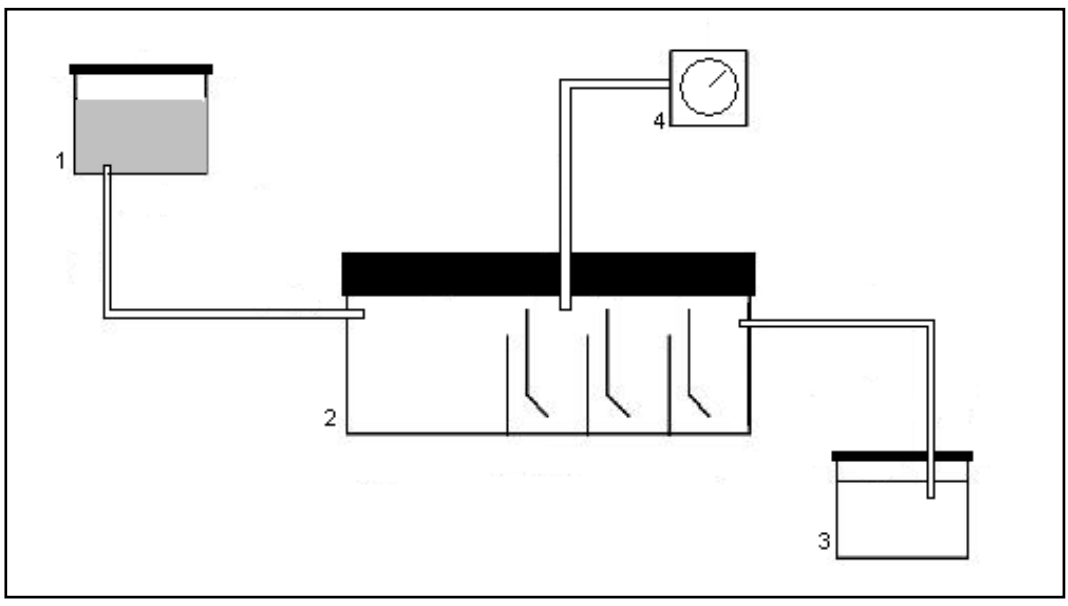

Figure 1: Laboratory scale anaerobic baffled reactor (1: influent tank, 2: ABR system, 3: effluent tank, 4: wet gas meter).

The first compartment of a four-chamber unit, which was 34 liters, was bigger in size while the following compartments were 17 liters. This physical modification provided longer solids retention time and superior performance as compared to the reactor with similar size compartments. The larger compartment in the reactor acted as a natural filter and provided superior solids retention for the small particles. This configuration collected more solid materials than the reactor with four of the similar size chambers [8]. The edges on baffles slanted at $45^{\circ}$ to route the flow towards the center of the compartment and, hence, encourage mixing.

\subsection{Feedstock preparation}

Based on characteristics of kitchen waste and its high $\mathrm{C} / \mathrm{N}$ ratio [1], different percentages of kitchen waste were mixed with sewage sludge as a source of Nitrogen to normalize the value of $\mathrm{C} / \mathrm{N}$. The sewage sludge was collected from a wastewater treatment plant sewage sludge return pipeline and immediately brought to the laboratory. The $\mathrm{C} / \mathrm{N}$ ratio of sewage sludge used in the experiments, was $11 / 1$ with $5 \% \mathrm{~N}$ of dry weight. Four different combinations of kitchen waste and sewage sludge were compared to determine the best efficiency of methane gas generation in the shortest time (table 1).

Table 1: Percentages of kitchen waste and sewage sludge.

\begin{tabular}{|c|c|c|}
\hline Sample no. & Kitchen waste (\%) & Sewage sludge (\%) \\
\hline 1 & 100 & 0 \\
\hline 2 & 75 & 25 \\
\hline 3 & 50 & 50 \\
\hline 4 & 25 & 75 \\
\hline
\end{tabular}




\subsection{Analytical methods}

The characteristics of kitchen waste were initially determined. The wastes were taken from kitchen refuse of a cafeteria located at the university. "Part and quarterly methods" were used as standard procedures to prepare samples. Then, they were collected and combined in an approximately equal proportion and mixed thoroughly in the laboratory, shredded and grounded into a size of approximately $1 \times 1 \times 0.5 \mathrm{~cm}^{3}$ prior to analysis for chemical composition. Samples were analyzed for moisture content, total solids, total volatile solids, ash content, total organic carbon, Kjeldahl nitrogen, fat, protein, cellulose, hemi cellulose and lignin using analytical methods given by USEPA [9]. The $\mathrm{pH}$ of the slurry was measured using a digital $\mathrm{pH}$ meter having an accuracy of $\pm 0.01 \mathrm{pH}$ unit and the reactor was run in mesophilic conditions. Totally, 40 samples were measured and finally the average of each parameter was calculated. Gas samples were collected by gas sampling injectors and a sample of $100 \mu \mathrm{l}$ was used for each run. The biogas composition $\left(\mathrm{CH}_{4}+\mathrm{CO}_{2}\right)$ was determined by using a Gas Chromatograph (NUCON 5700) equipped with a thermal conductivity detector and stainless steel column of $6 \mathrm{ft}$ length, 1/4 inch OD, 2 mm ID, containing Porapak Q 100 having mesh range $80-100$. The carrier gas used was $\mathrm{H}_{2}$ and the analysis was carried out at a carrier gas flow rate of $30 \mathrm{ml} / \mathrm{min}$ with the injector, column and detector temperatures maintained at 120,90 and $120^{\circ} \mathrm{C}$, respectively. Gas volume was measured using a water displacement method. To measure the fertilizer values, concentration of Nitrogen, Phosphorus and Potassium in produced sludge in the Anaerobic Baffled Reactor (ABR), analytical methods given by APHA [10] were used.

\section{Results and discussion}

\subsection{Kitchen waste characteristics}

Table 2 shows the chemical composition of kitchen waste. For the purpose of gas generation the solid content of feed material should be approximately 10-15 percent [11]. Total solids were found between 10.4 to $20.7 \%$ with the average of $14.8 \%$. C/N ratio was another value that was calculated. Bacteria normally use up carbon 25-35 times faster than they use nitrogen. Therefore, at this ratio of $\mathrm{C} / \mathrm{N}$ $(25-35 / 1)$ the digester is expected to operate at an optimal level for gas production. The $\mathrm{C} / \mathrm{N}$ ratio for kitchen waste was found 38.2/1.

The substrate consists of complex organic polymers, which have a very important role in the first stage of anaerobic digestion of organic compounds and their presence is vital, because these organic polymers are broken down by extracellular enzymes produced by hydrolytic bacteria, and dissolved in the water. The moisture content of kitchen waste was found $84.5 \%$. The high moisture content verified that kitchen waste was not ideal for incineration or landfill. 
Table 2: Chemical composition of kitchen waste.

\begin{tabular}{|l|c|}
\hline Parameters & Weight fraction (\%) or ratio \\
\hline Total solids & 14.8 \\
\hline Total volatile solids & 89.5 \\
\hline Ash & 10.5 \\
\hline Total organic carbon & 49.7 \\
\hline Kjeldahl nitrogen & 1.3 \\
\hline C/N weight ratio & 38.2 \\
\hline Fat & 8.7 \\
\hline Protein & 6.7 \\
\hline Cellulose & 14.9 \\
\hline Hemi-cellulose & 9.9 \\
\hline Lignin & 8.5 \\
\hline Moisture content & 84.5 \\
\hline
\end{tabular}

\subsection{Volatile fatty acid profile and $\mathrm{pH}$}

Changing of $\mathrm{pH}$ during anaerobic digestion for all mixtures is illustrated in fig. 2 . After 16 days of digestion, the kitchen waste alone was still in its acid formation phase, as indicated by the slightly acidic leachate collected $(\mathrm{pH}=5.92)$. High $\mathrm{CO}_{2}$ and low $\mathrm{CH}_{4}$ contents are the best indicators of the digestion process not having reached active methanogenesis [12]. For other samples (samples 2 to 4), the $\mathrm{pH}$ variation could be categorized into 3 main zones. The first zone started from the first day till the $4^{\text {th }}$ day, which showed a drastic drop of the $\mathrm{pH}$. This is due to high development rate of volatile fatty acid by the microorganism. The second zone started from the $5^{\text {th }}$ till the $12^{\text {th }}$ day of the experiment. In the second zone, the $\mathrm{pH}$ was in the range of 6.9 to 7.3. This is due to the development of $\mathrm{CO}_{3} \mathrm{HNH}_{4}$ from $\mathrm{CO}_{2}$ and $\mathrm{NH}_{3}$, which were produced during the anaerobic process. The percentage of $\mathrm{CO}_{3} \mathrm{HNH}_{4}$ had caused the increase alkalinity of the samples. Due to this, any differences in the volatile fatty acid content did not affect the $\mathrm{pH}$ value. The third zone started on the $13^{\text {th }}$ till the last day of the experiment. In this zone, it was found that the $\mathrm{pH}$ value of the samples started to increase. This is due to the development of $\mathrm{CO}_{3} \mathrm{HNH}_{4}$ still continuing, but no more volatile fatty acid was produced.

\subsection{Gas production and composition}

Gas production in each sample is illustrated in fig. 3. Kitchen waste alone produced $0.050 \mathrm{~m}^{3} / \mathrm{kg}$ VS biogas after 16 days. The combination of $75 \%$ kitchen waste $25 \%$ sewage sludge had a relatively high gas production rate of $0.594 \mathrm{~m}^{3}$ per $\mathrm{kg} \mathrm{VS}$, while the gas production for samples 3 and 4 was 0.201 and 0.151 $\mathrm{m}^{3} / \mathrm{kg}$ VS, respectively. 


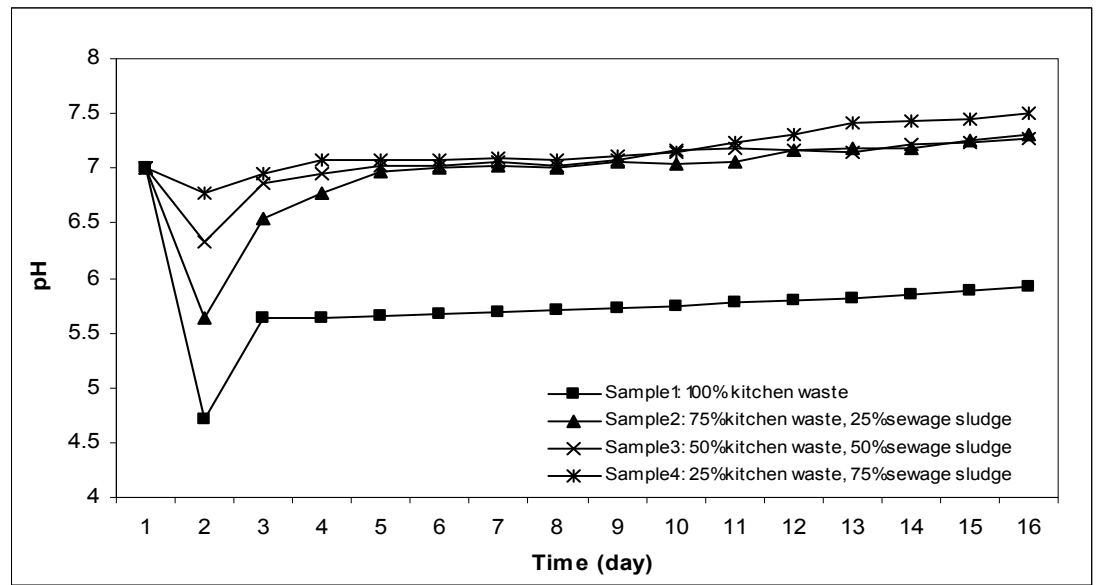

Figure 2: $\mathrm{pH}$ variation of the samples during anaerobic process.

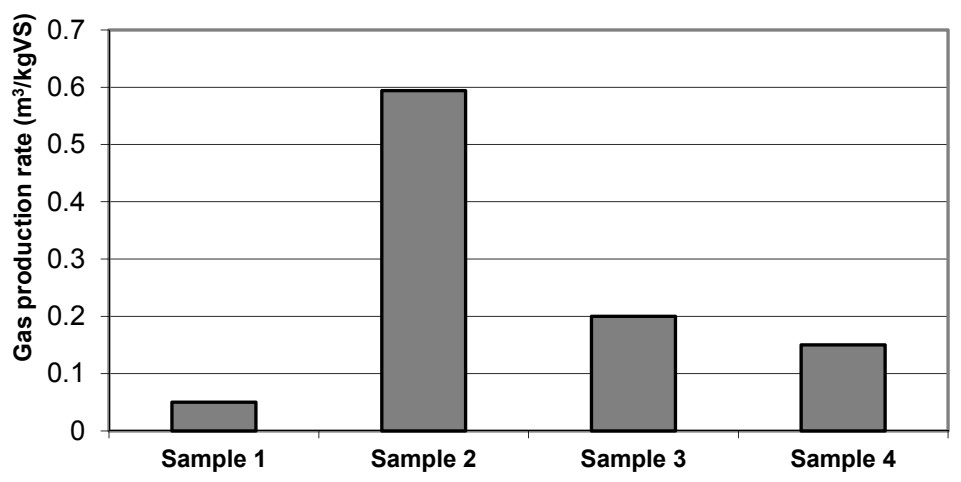

Sample 1: 100\% kitchen waste.

Sample 2: $75 \%$ kitchen waste, $25 \%$ sewage sludge

Sample 3: $50 \%$ kitchen waste, $50 \%$ sewage sludge

Sample 4: $25 \%$ kitchen waste, $75 \%$ sewage sludge

Figure 3: Gas production in the mixtures after 16 days.

After 16 days of digestion, the kitchen waste alone was still in its acid formation phase, as indicated by the slightly acidic leachate collected. Furthermore, the relatively high level of $\mathrm{CO}_{2}$ and low level of $\mathrm{CH}_{4}$ from kitchen waste alone throughout the whole experimental period (fig. 4) indicated that a longer period was needed for the kitchen waste to go through the acidogenic and acetogenic phases. High $\mathrm{CO}_{2}$ and low $\mathrm{CH}_{4}$ contents are the best indicators of the digestion process not having reached active methanogenesis [12]. 


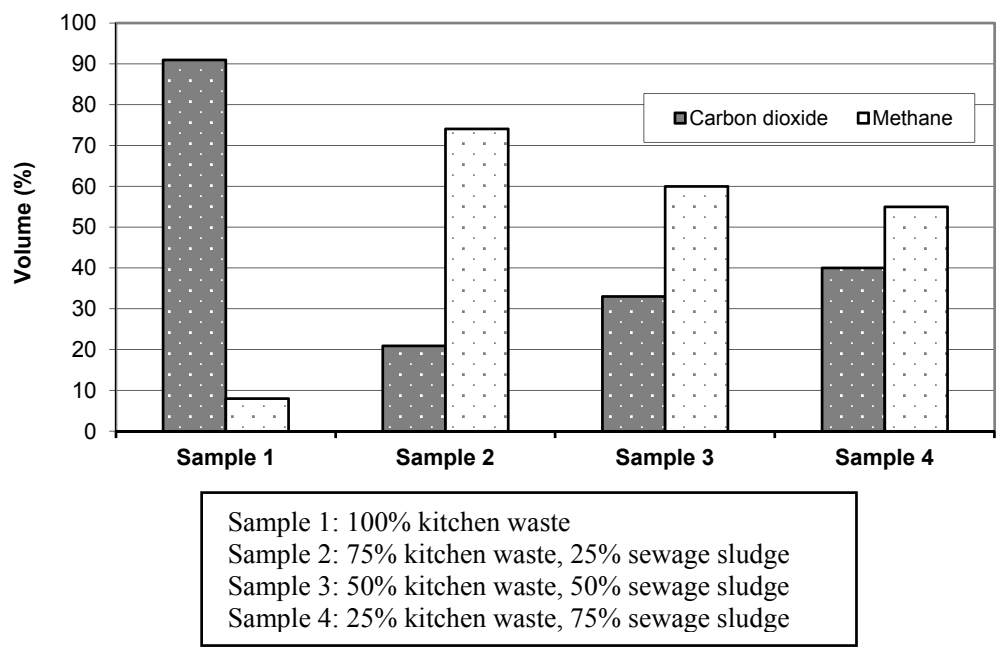

Figure 4: Level of $\mathrm{CH}_{4}$ and $\mathrm{CO}_{2}$ in the mixtures after 16 days.

The waste mixtures (samples 2, 3 and 4) produced biogas with high methane content, indicating that the slurries had the proper microbial populations to start the anaerobic degradation. Among them, Sample 2 had the best performance, which may depend on food-to-microorganisms ratio $(\mathrm{F} / \mathrm{M})$. The growth of microorganisms in a system is depended on the F/M ratio and if this is decreased, then the microorganisms will go to a death phase and flocs will be formed [13]. From microbiological point of view, the sewage sludge contains a mixture of microorganisms that need food to continue their life and when compared with kitchen waste, sewage sludge has low potential for gas production, as most chemical energy in the sludge has already been depleted in the aeration tank. Polprasert have confirmed that mixing waste at a proper ratio can enhance the digestion process and shorten the time to reach the final phase of anaerobiosis [11]. While gas production for the mixture at $75-25$ had started immediately after running the reactor and reached the highest amount of $0.594 \mathrm{~kg} / \mathrm{m}^{3}$ VS after 16 days, the sample with $100 \%$ kitchen waste could only produce $0.05 \mathrm{~kg} / \mathrm{m}^{3} \mathrm{VS}$ in the same duration (fig. 5).

\subsection{NPK values determination}

The amounts of $\mathrm{N}, \mathrm{P}$ and $\mathrm{K}$ as the three essential plant microelements were found $0.95,0.80$, and $0.45 \%$, respectively. A comparison between the value of NPK in the ABR and other sources [14] shows that, except from city refuse, the NPK value in produced sludge in ABR is higher than that in rural refuse and also plant residues (fig. 6). However, to compare to chemical fertilizer, the amounts of N, P and $\mathrm{K}$ even in city refuse is several time lower and, for better efficiency, the ABR sludge needs to be mixed with chemical fertilizer. 


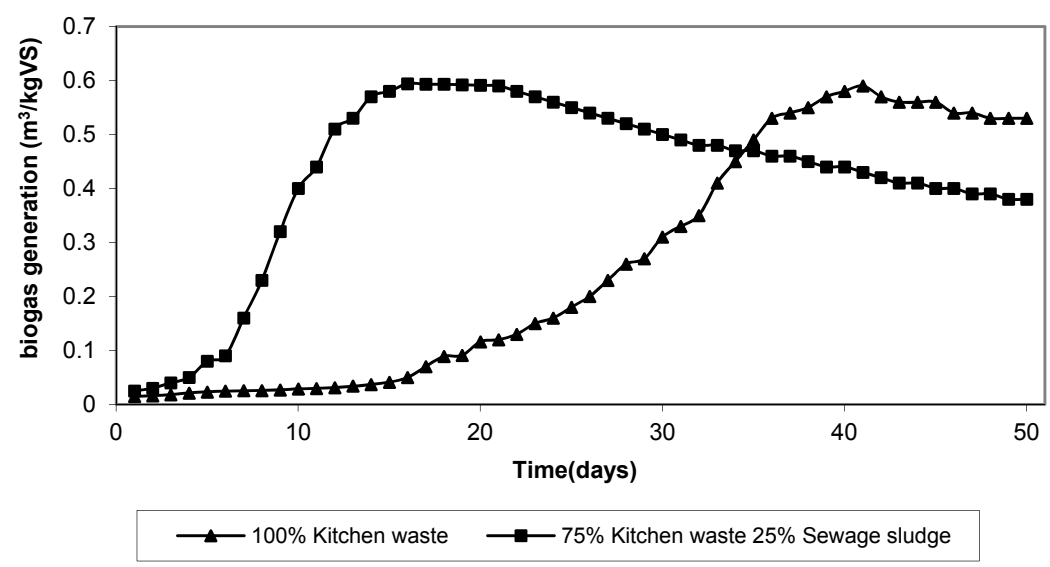

Figure 5: Comparison between $100 \%$ kitchen waste and mixture of $75 \%$ kitchen waste and $25 \%$ sewage sludge.

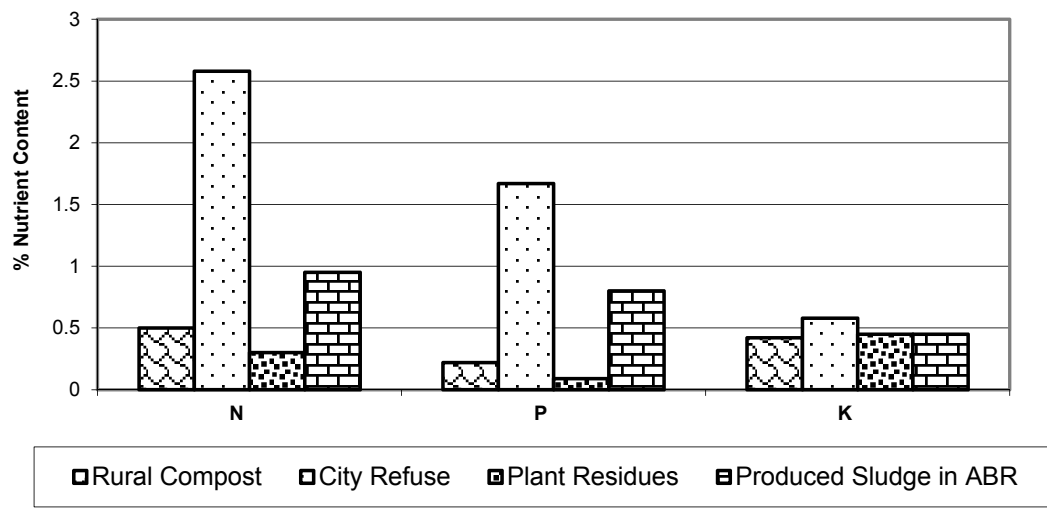

Figure 6: Comparison between NPK values in ABR system with other sources.

\section{Conclusion}

The environmentally acceptable management of municipal solid waste has become a global challenge due to limited resources, ever increasing population, rapid urbanization and industrialization worldwide. The modified ABR showed the proper performance in biogas production and could be a reasonable choice for energy production as well as a system for the processing of organic parts of produced solid waste. Among all the samples the mixture with $75 \%$ of kitchen 
waste and $25 \%$ of sewage sludge had the best biogas and methane production competence due to its suitable $\mathrm{C} / \mathrm{N}$ and $\mathrm{F} / \mathrm{M}$ ratio. NPK value in produced sludge in $\mathrm{ABR}$ is lower than those present in chemical fertilizers and thus the former needs to be mixed with chemical fertilizer prior to being used as fertilizer.

\section{Acknowledgements}

This paper was supported by Universiti Teknologi PETRONAS and Universiti Kebangsaan Malaysia (project code: KK008/2004). Their cooperation with the authors is fully appreciated.

\section{References}

[1] Malakahmad, A., Ahmad Basri, N. \& Md Zain, S., Proc. of the $2^{\text {nd }}$ Int. Conf. on Environmental Management, eds. J.M. Jahi, K. Arifin, S. Surif \& S. Idrus, Environmental Management Society Malaysia: Bangi, pp. 41-47, 2004.

[2] Baloch, M.I., Akunna, J.C. \& Collier, P.J., The performance of a phase separated granular bed bioreactor treating brewery wastewater. Bioresource Technology, 98(9), pp. 1849-1855, 2006.

[3] Malakahmad, A., Ahmad Basri, N. \& Md Zain, S., Proc. of the $1^{\text {st }}$ Conf. on Energy and Environment, eds. K. N. Chee, M. O. Abdullah, A. R. H. Right, M. S. Osman, Universiti Malaysia Sarawak: Kuching, pp. 108-110, 2007.

[4] Huttunen, S. \& Lampinen, A., eds., Bioenergy Technology Evaluation and Potential in Costa Rica, University of Jyväskylä Printing House: Jyväskylä, Finland, pp. 40-44, 2005.

[5] Berglund, M. \& Börjesson, P., Assessment of energy performance in the life-cycle of biogas production. Biomass and Bioenergy, 30, pp. 254-266, 2006.

[6] Lansing, S., Botero, R.B. \& Martin, J.F., Waste treatment and biogas quality in small-scale agricultural digesters. Bioresource Technology, 99(13), pp. 5881-5890, 2008.

[7] Malakahmad, A., Ahmad Basri, N. \& Md Zain, S., Proc. of the LUCEDI\&UA Int. Conf. on Environmental Management \& Technology, ed. P. Agumuthu, Malaysian University Consortium for Environment and Development: Putrajaya, pp. 101-109, 2003.

[8] Barber, W.P. \& Stuckey, D.C., The use of the anaerobic baffled reactor (ABR) for wastewater treatment: a review. Water Resource, 33, pp. 1559-1578, 1999.

[9] Test Methods for Evaluating Solid Waste, Physical/ Chemical Methods; U.S. Environmental Protection Agency, Office of Solid Wastes, SW-846 Online. www.epa.gov/epaoswer/hazwaste/test/main.htm

[10] APHA - AWWA, Standard Methods for Water and Wastewater Examinations. $21^{\text {st }}$ ed. American Public Health Association/American Water Works Association: Washington, DC, 2005. 
[11] Polprasert, C., Organic Waste Recycling, $2^{\text {nd }}$ ed., John Wiley and Sons Publication: Chichester, pp. 25-47, 1996.

[12] Pohland, F.G. \& Ghosh, S., Developments in Anaerobic Treatment Processes in Biological Waste Treatment, $2^{\text {nd }}$ ed., Canale Interscience Publication: New York, 1971.

[13] Shariat, M., Principle of Microbiology in Water and Wastewater Treatment, Publication of Tehran University: Tehran, 2002.

[14] Polprasert, C., Edwards, P., Pacharaprakiti, C., Rajpot, V.S. \& Suthirawut, S., Recycling rural and urban nightsoil in Thailand, AIT Research Report, Asian Institute of Technology: Bangkok, 1982. 